\title{
Perancangan Sistem Mekanis Alat Pencabut Singkong untuk Optimasi Sistem Panen Bagi Petani Singkong di Kelurahan Borong Loe Kecamatan Bontomarannu Kabupaten Gowa
}

\author{
Sapta Asmal', Syamsul Bahri, Muhammad Rusman, Rosmalina Hanafi, \\ Saiful, Farid Mardin, Nilda, Nadzira Ikasari \\ Departemen Teknik Industri Fak. Teknik Unhas* \\ saptaasmal@yahoo.com*
}

\begin{abstract}
Abstrak
Ubi kayu (singkong) yang biasa ditanam petani di Kelurahan Borong Loe Kecamatan Bontomarannu Kabupaten Gowa adalah ubi kayu (singkong) lokal. Waktu yang diperlukan dari proses penanaman sampai dengan ubi kayu siap dipanen \pm 6-7 bulan. Hasil panen singkong di jual untuk berbagai kebutuhan seperti sebagai salah satu bahan makanan yang cukup penting sebagai sumber asupan karbohidrat. Proses pemanenan yang digunakan oleh petani saat ini adalah masih menggunaan cara manual yaitu dengan mencabut dengan tangan. sehingga memerlukan waktu yang lama dan tenaga yang lebih dalam melakukan pencabutan umbi. Belum adanya alat atau teknologi yang digunakan dalam malakukan pemanenan ubi kayu (singkong), sehingga penggunaan tangan untuk proses pemanenan menyebabkan petani ubi kayu tersebut mudah mengalami kelelahan dan keluhan tangan yang sakit. Berdasarkan uraian diatas untuk menyelesaikan permasalahan yang dihadapi petani, maka diperlukan system mekanisasi peralatan untuk mencabut singkong dari dalam tanah. Melalui Program Pengabdian Kepada Masyarakat Unhas- Program Kemitraan Masyarakat, maka dirancang dan dibuat teknologi tepat guna berupa alat pencabut singkong dengan system mekanisasi untuk memudahkan petani Kelurahan Borong Loe $\mathrm{Kab}$. Gowa dalam memanen hasil kebun singkongnya. Dari hasil penelitian dan pengukuran gaya angkat dilapangan yang telah dilakukan pada uji coba alat tersebut mampu merubah gaya tekan dari tangan operator sebesar 334.49 N menjadi gaya angkat/tarik sebesar $2000 \mathrm{~N}$.
\end{abstract}

Kata Kunci: Desa Borong Loe; Optimasi ; Alat pencabut Singkong; Sistem Mekanis; Teknologi Tepat Guna.

\begin{abstract}
Cassava (cassava) which is commonly planted by farmers in Borong Loe Village, Bonto Marannu District, Gowa Regency is local cassava. The time needed from the planting process until the cassava is ready for harvest $\pm 6-7$ months. Cassava crops are sold for various needs such as one of the important food ingredients as a source of carbohydrate intake. The harvesting process used by farmers today is still using the manual method, which is to use hand pulling. so it requires a long time and more energy in extracting the tubers. The absence of tools or technology used in harvesting cassava (cassava), so the use of hands for the harvesting process causes the cassava farmers to easily experience fatigue and complaints of sick hands. Through the Unhas Community Service ProgramCommunity Partnership Program, the appropriate technology is designed and made in the form of a cassava extractor with a mechanization system to facilitate farmers in harvesting their cassava yields. From the results of research and measurement of lift force in the field that has been carried out in the trial the tool is able to change the compressive force of the operator's hand at $334.49 \mathrm{~N}$ to lift or pull force of $2000 \mathrm{~N}$.
\end{abstract}

Keywords: Borong Loe Village; Optimization; Cassava extractor; Mechanical system;Appropriate Technology.

\section{Pendahuluan}

Kelurahan Borong Loe Kab. Gowa merupakan penghasil ubi kayu (singkong) dengan rata-rata produksi 15-20 kuintal/ha. ubi kayu (singkong) yang biasa ditanam petani Desa Borong Loe adalah ubi kayu (singkong) lokal. Waktu yang diperlukan dari proses penanaman sampai dengan ubi kayu (singkong) siap dipanen $\pm 6-7$ bulan. Hasil panen ubi kayu (singkong) di jual untuk berbagai kebutuhan seperti sebagai salah satu bahan makanan yang cukup penting sebagai sumber asupan karbohidrat. 
Proses pemanenan yang digunakan oleh petani saat ini adalah masih menggunaan cara manual yaitu dengan mencabut dengan tangan. sehingga memerlukan waktu yang lama dan tenaga yang lebih dalam melakukan pencabutan umbi. Belum adanya alat atau teknologi yang digunakan dalam malakukan pemanenan ubi kayu (singkong), sehingga penggunaan tangan untuk proses pemanenan menyebabkan petani ubi kayu tersebut mudah mengalami kelelahan dan keluhan tangan yang sakit.

Berdasarkan uraian diatas untuk menyelesaikan permasalahan yang dihadapi petani, maka diperlukan system mekanisasi peralatan untuk mencabut singkong dari dalam tanah. Melalui Program Pengabdian Kepada Masyarakat Unhas- Program Kemitraan Masyarakat, maka dirancang dan dibuat teknologi tepat guna berupa alat pencabut singkong dengan system mekanisasi untuk memudahkan petani Kelurahan Borong Loe Kab. Gowa dalam memanen hasil kebun singkongnya.

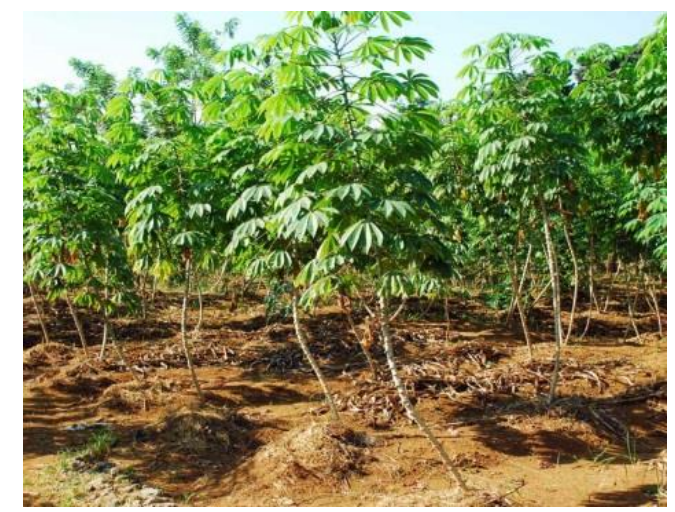

Gambar 1. Kebun Singkong yang Berlokasi di Kel. Borong Loe Kec. Bontomarannu Kab. Gowa

\section{Latar Belakang}

\subsection{Tanaman Singkong}

Ketela pohon atau ubi kayu merupakan tanaman perdu. Ketela pohon berasal dari benua Amerika, tepatnya dari Brasil. Penyebarannya hampir ke seluruh dunia, antara lain Afrika, Madagaskar, India, dan Tiongkok. Tanaman ini masuk ke Indonesia pada tahun 1852. Ketela pohon berkembang di negara- Negara yang terkenal dengan wilayah pertaniannya (Purwono, 2009).

Para petani biasanya menanam tanaman singkong dari golongan singkong yang tidak beracun untuk mencukupi kebutuhan pangan. Sedangkan untuk keperluan industri atau bahan dasar untuk industri biasanya dipilih golongan umbi yang beracun. Karena golongan ini mempunyai kadar pati yang lebih tinggi dan umbinya lebih besar serta tahan terhadap kerusakan, misalnya perubahan warna (Sosrosoedirdjo, 1993).

\subsection{Panen Singkong}

Singkong dapat dipanen pada saat pertumbuhan daun bawah mulai berkurang. Warna daun mulai menguning dan banyak yang rontok. Umur panen tanaman ketela pohon telah mencapai 6-8 bulan untuk varietas Genjah dan 9-12 bulan untuk varietas Dalam. Pemanenan singkong di lakukan dengan cara mencabut batangnya dan umbi yang tertinggal diambil dengan cangkul atau 
garpu tanah (Rukmana 1997). Untuk varietas Manggu sendiri dapat dipanen pada usia 7 - 10 bulan.

Berdasarkan umurnya singkong dapat dibagi menjadi dua yaitu (Lingga 1986) :

a. Berumur pendek. Singkong yang berumur pendek berarti usia sejak mulai tanam sampai musim panen relatif lebih singkat yakni berumur $5-8$ bulan. Dalam seusia itu singkong dapat dipanen hasil maksimal. Andaikata panennya ditunda atau diperpanjang dari usia sebenarnya akan timbul masalah yakni umbinya banyak yang berkayu.

b. Berumur panjang. Jenis kedua yakni yang berumur panjang anatara 12-18 bulan. Bila dipanen sebelum usia tersebut, hasilnya mengecewakan karena umbinya kecil-kecil dan kandungan patinya sedikit. Jadi, paling tepat kalau dipanen setelah berumur 12-19 bulan.

\subsection{Mesin Pemanen Singkong}

Sejauh ini ada beberapa macam mesin atau alat pemanen singkong, ada yang memiliki kebutuhan daya tinggi dan ada juga yang hanya berupa alat bantu dioperasikan secara manual. Salah satu mesin pemanen singkong yang sudah ada.

\subsection{Alat Pemanen Singkong Mekanis}

Petani pada umumnya memanen singkong secara manual menggunakan tangan atau menggunakan alat bantu sederhana seperti cangkul dan garpu tanah. Selain dengan cara manual tersebut panen singkong juga bisa dilakukan dengan menggunakan alat mekanis. Spesifikasi alat ini adalah: lebar depan $40 \mathrm{~cm}$, lebar samping $40 \mathrm{~cm}$, tinggi $70 \mathrm{~cm}$ dan panjang tangkai $200 \mathrm{~cm}$.
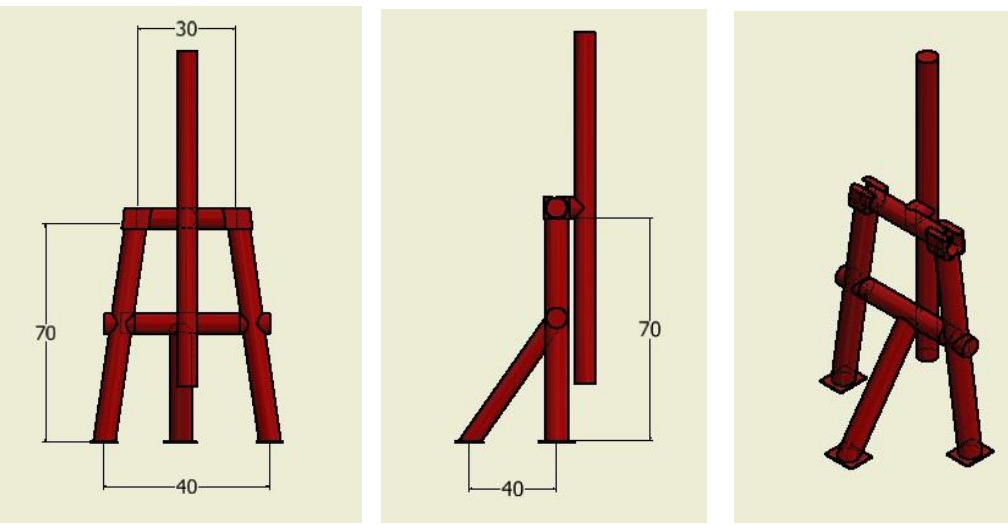

Gambar 2. Desain Alat Pencabut Singkong Mekanis (Sapta Asmal 2019)

\section{Metode}

Metode kegiatan yang dilakukan adalah dengan melakukan identifikasi permasalahan dilapangan yang dihadapi petani yaitu sulitnya mencabut Ubi kayu (singkong) oleh para petani. Mereka mengalami kendala ketika akan panen hasil kebun mereka, dikareka keras dan masih menggunkaan tenaga manusia tanpa bantuan alat. Selanjutnya setelah diidentifikasi, maka tim melakukan perangcangan alat dengan menggunakan teknologi sedehara dengan prinsip mekanis yang diperlukan dalam pemcabutan Ubi kayu (singkong) tersebut. Setelah data data didapatkan berupa tinggi pihon ubi kayu, kedalaman ubi kayu kedalam tanah, jarak pengungkit yang akan digunakan, dan seterusnya. Maka alat rancangan pencabut ubi kayu di gambar dan dimodelkan. 
Selanjutnya di buatkan konsep dan diskusi dengan para petani bersama tim yang dibentuk. Dalam kegiatan ini, jenis ubi kayu, kekerasan tanah, dan hal lainya di pertimbangkan dalam merangcang alat ini. Setelah jadi maka digambarkan alat pencabut ini dalam drawing tools. Yang kemudian di periksa kembali dengan jenis material yang akan digunakan.

\subsection{Sasaran}

Sasaran kegiatan pengabdian ini adalah warga masyarakat petani lading berupa ubi kayu (singkong) di desa bontomarannu kabupaten gowa. Survey awal menjelaskan bahwa warga di lokasi ini sangat mengharapkan pengetahuan dan keterampilan tentang penggunaan teknologi sedehana dalam pencabutan ubi kayu ini, dimana selama ini mereka menggunakan cara tradisional. Diharapkan nantinya aktivitas petani lading ubikayu (singkong) ini dalam lebih efektif dan efisien mengunakan tenaga, waktu dan pengelolaan yang tepat sehingga menjadi suatu kebiasaan yang bermanfaat di masyarakat.

\subsection{Metode Kegiatan}

Kegiatan pengabdian ini dilakukan dengan mendatangi lokasi kegiatan, yaitu di pemukiman para petani ubi kayu kampung bontomarannru kabupaten gowa. Para masyarakat diminta untuk berkumpul di salah satu tempat, kemudian diberikan materi tentang manfaat teknologi tepat guna untuk bidang pertanian khususnya untuk ubi kayu (singkong).

Selanjutnya, diberikan contoh/demonstrasi pancabutan singkong di kebun salah satu warga desa kampung bontomarannu kabupaten gowa. Untuk menambah motivasi warga masyarakat Kampung dalam menambah income keluarga dikarenakan efisien waktu yang digunakan sehingga tenaga dan waktu bisa digunakan untuk keperluan yang lain. Sehingga nanti dapat di hemat waktu untuk pemanen yang tadi nya butuh beberapa hari untuk luar kebun tertentu, sekarang jadi lebih cepat.

\subsection{Langkah-langkah Kegiatan}

Dalam perancangan alat ini, setelah rangcangan dan diskusi serta membuat alat pencabut ubi kayu (singkong) ini juga dilaksanakan pelatihan. Dalam kegiatan pelatihan ini juga disampaikan materi tentang teknik memanam, yakni jarak antar pohon, Teknik memasang alat pencabut ubi kayu, Teknik pencabutan itu sendiri yang efektif.

\section{Hasil dan Diskusi}



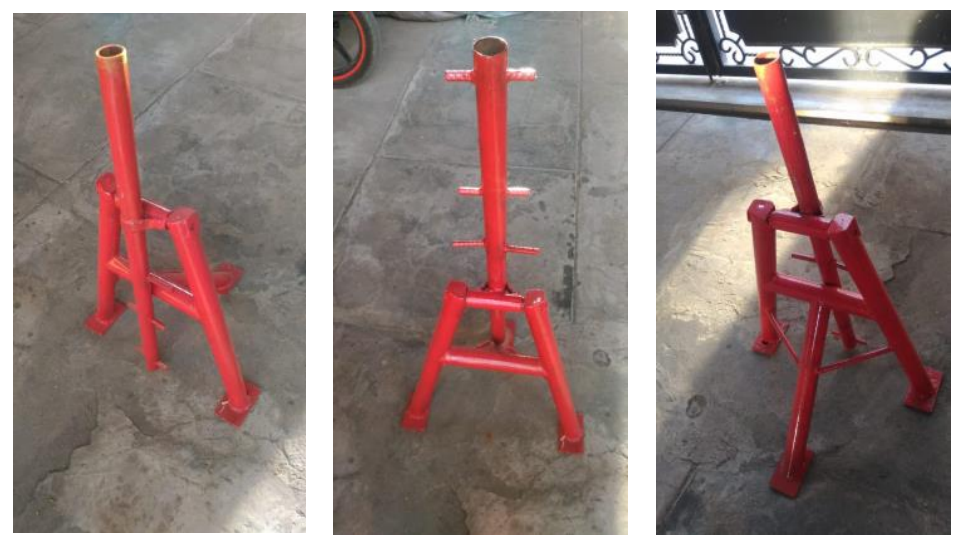

Gambar 3. Alat Pencabut Singkong Mekanis Hasil Rancangan (Sapta Asmal 2019)

\subsection{Uji Coba lapangan}
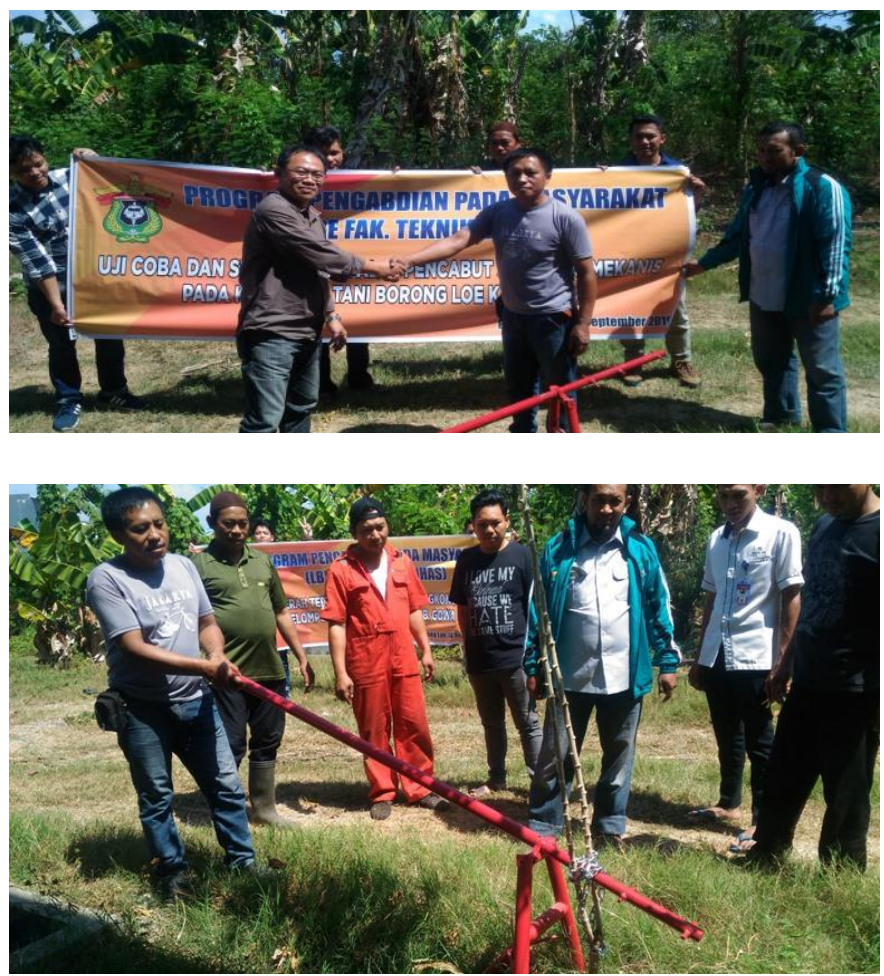

Gambar 4. Pelatihan Cara Penggunaan Alat Pencabut Singkong dan Serah Terima Peralatan Alat Pencabut Singkong Mekanis

Alat pemanen singkong mekanis tersebut menggunakan prinsip kerja momen gaya dengan sedikit usaha yang dilakukan tetapi dapat menghasilkan gaya angkat yang besar untuk mengangkat singkong. Selain itu alat tersebut terbuat dari bahan pipa baja ringan sehingga mudah untuk dipindahkan. Dari hasil penelitian yang sudah dilakukan, alat tersebut mampu merubah gaya tekan dari kaki operator sebesar $334.49 \mathrm{~N}$ menjadi gaya angkat/tarik sebesar 2000 N (Akinwonmi dan Andoh 2013).

\section{Kesimpulan}


Dari hasil uji coba dilapangan dapat ditarik kesimpulan: Alat pemanen singkong mekanis tersebut menggunakan prinsip kerja momen gaya dengan sedikit usaha yang dilakukan tetapi dapat menghasilkan gaya angkat yang besar untuk mengangkat/mencabut singkong dari dalam tanah. Selain itu alat tersebut terbuat dari bahan pipa baja ringan sehingga mudah untuk dipindahkan. Dari hasil penelitian dan pengukuran gaya angkat dilapangan yang sudah dilakukan pada uji coba alat tersebut mampu merubah gaya tekan dari tangan operator sebesar $334.49 \mathrm{~N}$ menjadi gaya angkat/tarik sebesar $2000 \mathrm{~N}$.

\section{Ucapan Terima Kasih}

Tim Pengabdian Masyarakat mengucapkan terima kasih kepada LBE Fakultas Teknik Universitas Hasanuddin Makassar, yang telah memberikan kesempatan dan bantuan kepada kami untuk melakukan kegiatan Pengabdian Masyarakat ini. Dan tidak lupa juga kami mengucapkan banyak terima kasih kepada Pemerintah dan Warga Masyarakat kampung bontomarannu kabupaten gowa atas bantuan dan kerjasamanya selama kami melakukan kegiatan ini.

\section{Daftar Pustaka}

Danarti, Najiyati S. 1998. Palawija, Budidaya dan Analisis Usaha Tani. Jakarta (ID): Swadaya. Darun. 2002. Ekonomi Teknik. Jurusan Teknologi Pertanian Fakultas Pertanian USU, Medan. Daywin F .J. R .G Sitompul dan Hidayat. 2008. Mesin-Mesin Budidaya Pertanian di Lahan Kering.Graha Ilmu: Jakarta.

Kurniawan B J.2017. Desain Fungsional Unit Penanam Stek Singkong [skripsi]. Bogor(ID):Institut Pertanian Bogor.

Purba R. 1997. Analisa Biaya dan Manfaat. PT. Rineka Cipta : Jakarta.

Ridho M. 2017. Rekayasa Fisik Arah Tumbuh Umbi Singkong Untuk Pemanenan Mekanis [skripsi]. Bogor(ID): Institut Pertanian Bogor.

Sagala E., 2014. Manajemen Panen dan Pasca Panen Ubi Kayu (Manihot esculenta Crantz) PT Pematang Agri Lestari Untuk Bahan Baku Industri Tapioka PT Sinar Pematang Mulia I [skripsi]. Bogor(ID): Institut Pertanian Bogor.

Sukirno. 1999. Mekanisasi Pertanian. UGM. Yogyakarta.

Sularso., \& Suga, K. 1985. Dasar Perencanaan Dan Pemilihan Elemen Mesin. Jakarta : Pradnya Paramita.

Ubaidillah S. 2009. Studi Penggupasan Kulit Singkong Dengan Pisau Melingkar [skripsi]. Bogor(ID): Institut Pertanian Bogor.

Waldiyono. 2008. Ekonomi Teknik (Konsep Teori dan Aplikasi). Pustaka Pelajar : Yogyakarta. 